\title{
Good theory: developing a foundation for project management
}

\author{
Kam Jugdev \\ Project Management and Strategy, \\ Centre for Innovative Management, \\ Athabasca University, 8311-11 Street SW, \\ Calgary, Alberta, T2V 1N7, Canada \\ Fax: 403-301-2986_ E-mail:kamj@athabascau.ca
}

\begin{abstract}
Project management is in its infancy when it comes to developing a theoretical foundation. Unless we develop a theoretical foundation, we run the risk of furthering the discipline in an atheoretical and ascientific way. In this paper, we frame the importance of collaboration between academics and practitioners in developing project management theory. We then discuss the challenges of developing a theoretical foundation and review the progress we have made in developing theories in project management. The paper concludes with suggestions on how to improve project management theory.
\end{abstract}

Keywords: epistemology; ontology; project management; philosophy of science; research; theory.

Reference to this paper should be made as follows: Jugdev, K. (2008) 'Good theory: developing a foundation for project management', Int. J. Product Development, Vol. 6, No. 2, pp.177-189.

Biographical notes: Kam Jugdev is an Associate Professor of Project Management and Strategy in the MBA Program at Athabasca University. She is also an Adjunct Professor at the Schulich School of Engineering, University of Calgary, Alberta. Her areas of research include project management as a source of competitive advantage, project lessons learned, project success/failure, and organisational learning. She actively contributes to the advancement of academic and professional communities of management practice.

\section{Introduction}

"There is nothing more practical than good theory." (Lewin, 1945, p.129)

Project management is a set of processes that encompasses the tools, techniques, and knowledge-based practices applied to projects to achieve organisational goals and deliver products or services (PMI, 2004). Although project management has unofficially been around since time immemorial when people started to coordinate activities with each other, such as building shelters, ships, and pyramids, it is a young discipline relative to other occupations. As discussed in this paper, the use of theories in project management is more implied than explicit and the theoretical foundations used need to be more clearly articulated. 
Young disciplines tend to use theories from more established fields until they develop their own theoretical foundation. For example, strategic management researchers draw from economics and use transaction cost theory and organisational theory researchers use communication theory to analyse group dynamics. Project management draws from the fields of social sciences, management, decision sciences, operations management, and engineering yet it is a challenge to identify several clear theories for the discipline.

A theory is a "coherent description or explanation of observed experienced phenomena" (Gioia and Pitre, 1990, p.587). A theory reduces "the incidence of practice based on incompletely espoused theories" (Lynham, 2000, p.159). The outcomes of theory development are that increased exploratory, explanatory, and predictive knowledge is developed along with the process knowledge of how something works (Lynham, 2000).

"Good theory is practical precisely because it advances knowledge in a scientific discipline, guides research towards crucial questions, and enlightens the profession of management." (van de Ven, 1989, p.486)

Interest in project management is mounting as evident by the increasing growth of project management professional associations and the global use of project management to help companies succeed (Cleland and Ireland, 2002; Pinto, 2001). Rigorous research encourages the use of evidence-based practice and can better position project management as a value-adding practice (Meredith, 2002). A theoretical foundation also helps a discipline mature in terms of knowledge and practice (Lynham, 2000). If publications are based on a set of assumptions and beliefs related to a theory, this lends credibility to papers and academics are more inclined to incrementally build on those concepts for future studies. Readers are also more inclined to accept and apply findings to practice if papers are from top tier rigorously peer reviewed journals. At present, project management has yet to be accepted as an established publication stream in the top journals.

Our aim in writing this paper is three-fold. First, our purpose is to frame the importance of collaboration between academics and practitioners in developing project management theory. Our second aim is to discuss how challenging it has been for management to develop its theoretical foundation so that we can draw implications for project management. Our third aim is to provide a preliminary snapshot on the progress made in developing theories in project management.

\section{Philosophy of science}

Theories are built through research. Research is the "scholarly or scientific investigation or inquiry" (Gioia and Pitre, 1990, p.162). Research contributes to new knowledge and theories are an important form of new knowledge. Theories involve different ontologies because theories are developed by researchers who hold different world views on reality and truth. People also hold different epistemologies, meaning that they create and organise knowledge differently.

As we examine theories in project management we should avoid falling into the trap of assuming that there is only one right way to develop theory or conduct research. Project management falls at the interface of the social sciences and hard management sciences such as operations and production management. If the term science is defined 
broadly to include the social sciences/humanities, we can argue the natural sciences approach was not consistently used to develop all 'science'. To further develop a theoretical foundation in young disciplines, we should encourage dialogue on and the use of multiple ways of building theory (ontologies and epistemologies) by drawing from natural scientific approaches that rely on cause and effect explanations as well as humanities approaches that use intentional and functional explanations (Elster, 1983). As the social sciences/humanities are evolving, they typically lack well-developed theories (Chalmers, 1999) and the literature may involve perspectives or views, which could evolve into theories over time.

"A good theory explains, predicts, and delights" (Weick, 1995a, p.155). However, good is a relative term. Characteristics of a good theory involve power, testability, simplicity and fertility (Arnoult, 1976). Power means that the theory correctly explains a variety of phenomena. Testability means that a theory clearly ascertains wrong predictions. A simple theory is elegant and involves few concepts and relationships. A theory is fertile when it offers new ideas to explore further. In essence, a good theory answers 'why', 'what', or 'how' questions in a complete and parsimonious manner (Weick, 1995b). A good theory is hard to produce routinely because goodness is multidimensional (DiMaggio, 1995).

Researchers and practitioners are better prepared when they understand their personal ontologies, biases, and the different epistemological approaches possible. This helps us constructively criticise studies and enables us to respect the contributions others make to the field, even if we may not agree with them. Just as the use of theories can lead to better project management practice, project management practice can help build better theories.

\section{Boyer's scholarship framework}

Boyer discusses four kinds of scholarship priorities for a professoriate - the scholarship of discovery (research), the scholarship of teaching (pedagogy), the scholarship of practice (application) and the scholarship of integration (critical analysis and interpretation) (Boyer, 1990). The forms of scholarship help develop and communicate theories.

Academics are instrumental in guiding how disciplinary theories are shaped because they devote years to publishing conceptual and empirical papers. Over time, as more academics focus on certain streams of research based on a theory, a broader and more defined picture of that theory emerges. The scholarship of practice is central to the work those in industry do and the scholarship of integration evident in how they relate the literature to practice. For example, management education students are often employed in middle to senior level positions within organisations and are in positions to apply what they learn at graduate school. Good research involves strong ties to practice, thereby strengthening the scholarship of practice.

Readers socially construct theory because the value of a theory depends on how readily it is disseminated and accepted by readers (DiMaggio, 1995). The dissemination of theories in practice helps establish the importance of certain theoretical foundations and over time, change our viewpoints. For example, several of Porter's 20-years old frameworks on competitive strategy (SWOT and the Five Forces Framework of Competitive Advantage) are rooted in the Industrial Organisation Economics theory 
(Porter, 1998). Over the years, the widespread use helped disseminate Porter's industry view of the firm but also enabled us to question the heavy emphasis on the industry as a source of competitive advantage, to a point where we are more focused now on what happens within the organisation as per the Resource Based view (Barney, 1991).

When we think of project management in the context of Boyer's framework (Boyer, 1990), it appears that the scholarship of practice has advanced as evident by the widespread use of the discipline world-wide and growth of education programs. Whereas in 1993 there were seven universities offering master's level degree programs in project management, today there are over 59 universities worldwide (PMI, 2007). A variety of education providers also offer certifications in project management. But, how evolved is the scholarship of discovery (research) in the discipline? There are mounting claims the field has a narrow focus and lacks both empirical depth and a theoretical basis (Engwall, 2003; Meredith, 2002; Packendorff, 1995; Shenhar and Dvir, 1996; Söderlund, 2003).

\section{Developments to date in project management theory}

"Most descriptive research on the management of projects is relatively young and suffers from a weak theoretical basis" (Engwall, 2003, p.792). Despite the areas of growth and development in the field, a search for academic papers specific to developing theory in project management was disappointing. Using ABI Inform ${ }^{\circledR}$, a search based on the words 'theory' and 'project management' in 2005 resulted in 120 academic papers. Although initially promising, very few papers addressed project management theory (Engwall, 2003; Packendorff, 1995; Söderlund, 2004). Adding the words 'epistemology' or 'ontology' as citation or paper text words to the words 'theory' and 'project management' did not result in any publications in ABI Inform ${ }^{\circledR}$. Both the Engwall and Packendorff papers addressed the history of project management and the topic of projects as temporary organisations as a 'theory' (Turner and Müller, 2003). ${ }^{1}$ These authors used the term 'theory' loosely as the papers did not address theory in the context of our paper.

According to Koontz (1980) management classification scheme, project management evolved through the decision theory and mathematics schools that were instrumental in the development of operations management and management science. Project management evolved in the 1950s from mathematical research based on algorithms and project planning techniques (e.g., network planning efforts involving Program Evaluation and Review Techniques and Critical Path Methods) (Engwall, 2003; Packendorff, 1995). Numerous project management textbooks focused on normative advice on planning and managing projects (Morris, 2001; Söderlund, 2003). This helped create a normative and rationalistic body of knowledge, but does not reflect a theory in and of itself. Over the years, a stream of literature in operations management was devoted to computer applications and expert systems for project planning, control, and risk analysis (Packendorff, 1995). The planning approach was criticised in the 1960s for an over emphasis on the rationalistic approach and this gave rise to a body of literature on project organisational structures and project leadership. 


\subsection{Dominant themes in project management publications}

Several sources portray the emerging theoretical schools within project management. The International Journal of Project Management ${ }^{\circledR}$ emphasises the temporary organisation viewpoint related to organisation theory (Söderlund, 2004). Another stream of publications within the International Research Network on Organising by Projects Conferences focuses on behavioural dimensions of projects in terms of politics, complexity, change, time, and learning (Söderlund, 2004). Project management involves two streams of research in the literature - one is the optimisation school that looks at work breakdown structures for the division of labour and network planning techniques for integrating tasks and the other school is the critical success factors one which examines generic factors on project success (Packendorff, 1995). Söderlund's indicates more generally, that project management involves two main theoretical traditions - one with its roots in the engineering sciences and applied mathematics and the other with its roots in the social sciences (sociology, organisational theory and psychology).

Two recent reviews reflect the breadth of topics covered in the academic publications. Kloppenborg and Opfer (2002) conducted a worldwide meta analysis of 3,554 project management papers (1960-1999). The authors defined project management research as:
"Published works based upon the data (either primary or secondary) and that make generalizable (sic) conclusions drawn from the data, where the data and conclusions are focused on either the project management context or the management activities (not the technical activities) needed to complete a project successfully." (Kloppenborg and Opfer, 2002, p.6)

Kloppenborg and Opfer found that in the 1970s, the literature focused on techniques i.e., software, work breakdown structures, and Program Evaluation and Review Techniques. In the $1980 \mathrm{~s}$, the literature was still rather technically oriented and covered design-to-cost, lifecycle costing, risk management, cost and schedule control, and control systems. However, the literature also started to address team building and quality. In the 1990s, the literature took more of a human resources approach and dealt increasingly with team-building and leadership topics. Recent project management literature focuses on competences, stakeholders, performance measures, and project management as a career path. The paper was a seminal contribution to the field because it categorised the kinds of publications noted in the journal databases. A limitation of Kloppenborg and Opfer's paper though, is that it did not address the theoretical underpinnings of the papers examined.

A scientometric (word association) review of 3,565 North American project management publications (1987-2001) confirmed that the emphasis in project management is on operations research, cost engineering, business process reengineering, and infrastructure studies (Ulri and Ulri, 2000) and that the theory of project management remains to be more clearly articulated. Ulri and Ulri viewed project management as a field of application and not one of fertile new thought; As supported by Meredith (2002), Ulri and Ulri noted that the relative importance of project management publications is not increasing. 
"This loss of centrality or density can be explained by the appropriation of concepts suitable for project management by more traditional and better anchored disciplinary fields such as finance, human resources management, or operations management." (Ulri and Ulri, 2000, p.40)

Project management publications are primarily evident in the International Journal of Project Management $^{\mathbb{B}}$ and the Project Management Journal ${ }^{\mathbb{R}}$. Operations management and engineering journals address project management but in a somewhat marginalised manner. Project management publications are rare in top tier management journals and such publications have a greater impact on the field (Podsakoff et al., 2005). This reflects how narrowly developed the field of project management is and the loss of publication density does not bode well for the discipline.

Just as there are multiple theories of organisational management and many mid-range theories, multiple theories of project management would also make sense and "the search for a universal theory may be inappropriate given the fundamental difference that exist across projects" (Söderlund, 2003, p.186). Just as management does not consist of a single theory, neither does project management as it is too broad a field (Morris, 2001). More often than not though, the theoretical basis of a paper is alluded to or implied but rarely explicitly stated in project management publications and in general the theoretical basis used, relates to a contingency approach, that is, 'it depends'. In light of the numerous and well developed theories that abound in the natural sciences and humanities, this is a major limitation in project management.

The next section turns to a brief overview of management theories to emphasise how arduous the task is of creating a theoretical foundation and then we discuss what needs to be done within project management to advance the discipline.

\section{Schools of thought in management theory}

Over the years, a number of publications attempted to organise and summarise the breadth and depth of management studies (Gonzalez et al., 2001; Koontz, 1980) and a coherent set of schools of management theory continue to be debated and developed. In 1980, Koontz identified 11 specific theoretical schools in management:

- Interpersonal Behaviour Approach based on psychology, human relations, leadership and motivation

- Group Behaviour Approach stemming from sociology

- Cooperative Social System approach which encompasses organisational theory

- Contingency or Situational Approach

- Decision Theory approach specific to decision making

- Mathematical or 'Management Science' Approach

- Socio-Technical Systems Approach - examining production, office operations, industrial engineering, and technology

- Systems Approach on the assemblage of concepts, principles, theory and techniques

- Managerial Roles Approach 
- Empirical or Case Approach

- Operational Theory Approach.

Focusing on the top journals in the field for 1992-1999, a co-citation approach and a multidimensional scaling technique mapped five dominant theories in management: Organisational Theory, Organisational Learning, Strategic Management, Transaction Cost Theory and Agency Theory (Gonzalez et al., 2001). A factor analysis identified eight factors which follow and are worth considering in the context of project management:

- Resources and Capabilities Theory

- Population Ecology - Including Organisational Change

- Contingent Approach

- Transaction Cost Theory

- Institutional Theory and Resources Dependency Theory

- Organisational Learning

- Strategic Management

- Agency Theory.

Both Koontz and Gonzalez agree on the Contingency Approach, yet differ on the other theoretical approaches. Koontz' categorisation involve a mix of management theories and research methods e.g., the case approach whereas Gonzalez' categorisation is more reflective of management theories.

Despite the advances over the past 50 years in management theory (Ghoshal, 2005; Gioia and Pitre, 1990; Kanter, 2005; Koontz, 1980; Lynham, 2000; Miner, 2003), progress continues to be described with terms decrying the need for better theory e.g., the theory jungle, the theory elephant, the theory ostrich, or the theory dinosaur (Redding, 1994). These metaphors lament how complex the domain is and the intensive work required to build theories. If management is concerned about the progress of theoretical development as assessed in top tier journals, what can we learn about the theoretical issues to be addressed in project management?

Spanning the last decade, Söderlund (2002) assessed the dominant schools of thought in the project management literature. Söderlund used an accepted guideline of top management journals to identify seven schools of thought.

- Optimisation school. This school is based on a systems analysis approach rooted in network planning research and systems analysis applications. The approach uses Program Evaluation and Review Techniques and critical path method techniques extensively along with scheduling and work breakdown techniques.

- Critical success factor school. This school primarily looks at the triple constraints of time, cost, and scope and has its roots in the need to address project failures. This approach examines success factors and project outcomes. 
- Contingency school. The contingency theory espouses that there is no best way to organise. The theory looks at the tasks, environment, technology, size and age of an organisation.

- Behavioural school. This is a very general viewpoint that was often implied vs. revealed in studies. The behavioural school looks at the process of organising the behaviour of project organisations and human interactions.

- Transaction cost school. This school examines why projects exist and governing mechanisms. Although the paper does not refer to agency theory (Eisenhardt, 1989) which addresses organisational governance, it is implied.

- Marketing school. This school examines how firms sell and market their projects.

- Decision school. This school is used in the pre project phase of why projects are instigated and why certain decisions made.

One could argue that a school which Söderlund identified as being specific to the project lifecycle should not be so narrowly defined. For example, the decision school is described in terms of the initiation phase yet key project decisions are made throughout the lifecycle. Söderlund's categorisation is also a mix of management theories and disciplines e.g., marketing school (Söderlund, 2002). Despite not using an existing management theories framework (Gonzalez et al., 2001; Koontz, 1980), his contribution to project management is important as it provides a preliminary categorisation.

The Söderlund (2002), Koontz (1980) and Gonzalez et al. (2001) categorisations all include the contingent approach and the Transaction Cost Theory was identified by both Söderlund and Gonzalez but not Koontz. It is interesting to see that Söderlund's Behavioural School relates to three of Koontz' approaches (Interpersonal Behaviour Approach, Group Behaviour Approach and Cooperative Social System Approach) and two of Gonzalez' approaches (Institutional Theory and Resources Dependency Theory and Organisational Learning). The emphasis on the Behavioural Approach is consistent with the pattern of project management publications within the International Journal of Project Management ${ }^{\mathbb{R}}$ and International Research Network on Organising by Projects Conferences.

Although project management lacks a well developed theoretical foundation, the discipline has developed some building blocks to help shape its theoretical foundation.

\section{A growing call for action}

In addition to project management being a young discipline, one reason we have not developed our own theoretical foundation has to do with research rigor within the discipline (Engwall, 2003; Meredith, 2002; Morris, 2001; Packendorff, 1995). The Project Management Journal ${ }^{\mathbb{R}}$ and International Journal of Project Management ${ }^{\mathbb{B}}$ represent key journals in the field. Assessments of these journals support the call for better theory in project management (Betts and Lansley, 1995; Engwall, 2003; Meredith, 2002; Morris, 2001; Packendorff, 1995). Betts and Lansley (1995) reviewed publications in the International Journal of Project Management ${ }^{\mathbb{B}}$ from 1983-1992. The papers were primarily reviews of practical experience $(58 \%)$ and case studies $(31 \%)$ but there were few empirical studies based on theories $(11 \%)$. Although helpful to practice, such 
contributions do not advance knowledge at the pace that theory-based publications might. The authors posit that the discipline needs to build and test models so that a theory of project management can emerge.

Although Meredith assessed a different journal for a decade beyond the period Betts and Lansley examined, his findings are similar and criticise project management publications on their research rigor (Meredith, 2002). Meredith assessed publications in the Project Management Journal ${ }^{\mathbb{R}}$ from 1995-2001. 63.2\% of the papers in the journal were of low methodological rigor and only $2.8 \%$ of the papers fit the high rigor category. In contrast, the other publications were based on tutorial, background, and war story approaches which are not recognised as research methodologies (Meredith, 2002). Meredith was critical of the main methodological approaches used in the Project Management Journal ${ }^{\mathbb{R}}$ as atheoretical and applied publications do not lend themselves to an accumulative research tradition. In 2002, at the Project Management Institute's ${ }^{\circledR}$ research conference, Project Management Journal ${ }^{\circledR}$ editors indicated that they were assessing this matter and aspired to have their journal at the top tier.

Our professional associations play a key role in helping build the theoretical foundation for the discipline. We currently have a number of project management associations to support the discipline. Each association developed a body of knowledge that it puts forth to its membership as the 'generally accepted' foundation for project management. These associations are exemplary in consensually developing the bodies of knowledge with their members and seeking broad agreement on them. The bodies of knowledge help members develop a common understanding of standard terms within the discipline. Associations have also led the way by widely distributing their bodies of knowledge and using them for certification purposes. Although we have bodies of knowledge in project management, these are not the same as a theoretical knowledge base.

Not only would it be advantageous for project management to develop one unified body of knowledge, but it would also be beneficial to have them articulate how the bodies of knowledge relate to project management's theoretical foundation. Koskela and Howell (2002) point out that the Project Management Body of Knowledge ${ }^{\circledR}$ Guide, for example, involves an 'implicit' theory stemming from operations management but no mention is made of an explicit theory (Koskela and Howell, 2002). As a first step, the knowledge areas could be used as building blocks to help articulate theoretical foundations of project management. Since the project management associations have a broad reach, it would be beneficial for them to address the importance of theory development to the discipline and support efforts to delineate these theories. In addition, there is a need for researchers to more clearly articulate the theories used. It is not possible to assess theory goodness if it is not explicitly and clearly articulated in conceptual and empirical papers.

To develop the theoretical foundation for project management, we can draw from the discussions in other young disciplines such as human resources which are intent on advancing theory. Some of the key arguments for the need for a theoretical foundation are that developing a theoretical foundation helps advance professionalism, maturity of the field, advances our knowledge base, and guides research on critical questions (Lynham, 2000). The time is right to examine the need for a theoretical foundation within project management before we become further entrenched on the current path. Without a theoretical foundation, we run the risk of building an atheoretical and ascientific practice that could undermine our ability to establish the discipline with greater credibility. We have a large constituency of project management practitioners (over 215,367 in the 
Project Management Institute ${ }^{\circledR}$, as of September 2006) (PMI, 2007), many of whom are unschooled in project management research yet judge publications for their usefulness to practice. We have an immense opportunity to help shape the future direction that project management takes.

"The ultimate judge of good theory in an applied field is primarily its practice" (Lynham, 2000, p.169). Building a project management theory with multiple world viewpoints will help lead to a more comprehensive, inclusive, and complete understanding of the human, social, and cognitive phenomena. To achieve this we should encourage dialogue on and the use of multiple ways of building theory. We should also more critically assess the research methods used in the journals and challenge the status quo (Meredith, 2002). Another approach to help heighten awareness on this important topic would be through conference tracks on theory building.

We will want to ensure that we effectively balance the need for academic rigor with practical relevance of publications (van de Ven, 1989). Tesch examined the project management Information Systems/Information Technology literature from 1999-2001 and found that the research did not closely relate to project management issues that practitioners thought were relevant to practice (Tesch et al., 2003). Other disciplines have done this very effectively as evident with the Academy of Management Executive ${ }^{\circledR}$, a top management journal that "provides practicing executives with relevant management tools and information based on recent advances in management theory and research" (Dutta and Crossan, 2005). Tesch expressed the need to foster more collaboration between academics and practitioners on research to ensure that the outputs were both sound and relevant.

We suggest two ways in which the theoretical foundation in project management could be developed. First, building on Söderlund's work, a study could review of the breadth of frameworks used to describe the main theoretical streams that are used in project management e.g., management, operations management, decision sciences etc. Then, a 10-year retrospective review of the key project management journals could be completed to identify the primary research streams each paper addresses. In doing so, empirical and conceptual papers could be assessed for their theoretical foundations, that is, what is the theory that was used to develop the paper's research question. Second, a citation analysis could be done to determine the impact of publications that are theoretically grounded. Papers that are theoretically grounded may well be published in top tier journals and are those that will have a greater impact on the field. It will take time to develop theories specific to project management and it will be an incremental process, but it is not an impossible undertaking.

\section{Conclusion}

Building on Söderlund's (2003) thesis that project management has a narrow focus, lacks empirical depth, and a theoretical basis, our aims in writing this paper were to frame the importance of collaboration between academics and practitioners in developing project management theory, discuss the challenges of developing a theoretical foundation, and review the progress we have made in developing theories in project management. We add our voice to that of others calling for more rigorous research and theory within project management (Packendorff, 1995; Shenhar and Dvir, 1996; Söderlund, 2003, 2004). 
These topics are relevant to readers because rigorous research encourages evidence-based practice. Good theory is not impossible to achieve as much as it takes time and is the standard to strive for. In part, developing good theory occurs in the context of the themes presented in this paper. Within the past 50 years we have made considerable progress in project management. However, we have a lot more work to do. We are confident that over time, the groundswell call of support for a more solid theoretical foundation for project management will be heard.

\section{Acknowledgements}

The author would like to acknowledge the generous support from Athabasca University and the University of Calgary.

\section{References}

Arnoult, M.D. (1976) Fundamentals of Scientific Method in Psychology, 2nd ed., William C. Brown, Dubuque, Indiana.

Barney, J.B. (1991) 'Firm resources and sustained competitive advantage', Journal of Management, Vol. 17, No. 1, pp.99-120.

Betts, M. and Lansley, P. (1995) 'International journal of project management: a review of the first ten years', International Journal of Project Management, Vol. 13, No. 4, pp.207-217.

Boyer, E.I. (1990) Scholarship Reconsidered: Priorities of a Professoriate, The Carnegie Foundation for the Advancement of Teaching, Princeton, New Jersey.

Chalmers, A.F. (1999) What is This Thing Called Science?, 3rd ed., Hackett Publishing Company Inc., Indianapolis, Indiana.

Cleland, D.I. and Ireland, L. (2002) Project Management: Strategic Design and Implementation, 4th ed., Vol. 1, McGraw-Hill, New York.

DiMaggio, P.J. (1995) 'Comments on 'what theory is not', Administrative Science Quarterly, Vol. 40, No. 3, pp.391-397.

Dutta, D.K. and Crossan, M.M. (2005) 'The nature of entrepreneurial opportunities: understanding the process using the 4I organizational learning framework', Entrepreneurship Theory and Practice, Vol. 29, No. 4, pp.425-449.

Eisenhardt, K. (1989) 'Agency theory: an assessment and review', Academy of Management Review, Vol. 14, No. 1, pp.57-74.

Elster, J. (1983) Explaining Technological Change, Cambridge University Press, Cambridge, England.

Engwall, M. (2003) 'No project is an island: linking projects to history and context', Research Policy, Vol. 32, No. 5, pp.789-808.

Ghoshal, S. (2005) 'Bad management theories are destroying good management practice', Academy of Management Learning and Education, Vol. 4, No. 1, pp.75-91.

Gioia, D.A. and Pitre, E. (1990) 'Multiparadigm perspective on theory building', Academy of Management Review, Vol. 15, No. 4, pp.584-602.

Gonzalez, F.J.A., Castro, C.B., Bueno, J.C.C. and Gonzalez, J.L.G. (2001) 'Dominant approaches in the field of management', The International Journal of Organizational Analysis, Vol. 9, No. 4, pp.327-353.

Kanter, R.M. (2005) 'What theories do audiences want? Exploring the demand side', Academy of Management Learning and Education, Vol. 4, No. 1, pp.93-95. 
Kloppenborg, T. and Opfer, W. (2002) 'The current state of project management research: trends, interpretations, and predictions', Project Management Journal, Vol. 33, No. 2, pp.5-18.

Koontz, H. (1980) 'The management theory jungle revisited', Academy of Management Review, Vol. 5, No. 2, pp.175-187.

Koskela, L. and Howell, G. (2002) 'The underlying theory of project management is obsolete', Paper presented at the Frontiers of Project Management Research and Application, July, Seattle, WA.

Lewin, K. (1945) 'The research center for group dynamics at Massachusetts Institute of Technology', Sociometry, Vol. 8, pp.126-135.

Lynham, S.A. (2000) 'Theory building in the human resources development profession', Human Resource Development Quarterly, Vol. 11, No. 2, pp.159-178.

Meredith, J.R. (2002) 'Developing project management theory for managerial application: the view of a research journal's editor', Paper presented at the Frontiers of Project Management Research and Application, July, Seattle, WA.

Miner, J.B. (2003) 'The rated importance, scientific validity, and practical usefulness of organizational behaviour theories: a quantitative review', Academy of Management: Learning and Education, Vol. 2, No. 3, pp.250-268.

Morris, P.W.G. (2001) Science, Objective Knowledge, and the Theory of Project Management, Unpublished Manuscript, London, England.

Packendorff, J. (1995) 'Inquiring into the temporary organization: new directions for project management', Scandinavian Journal of Management, Vol. 11, No. 4, pp.319-333.

Pinto, J.K. (2001) 'Project management: the future', in Knutson, J. (Ed.): Project Management for Business Professionals: A Comprehensive Guide, 1st ed., John Wiley \& Sons Inc., Hoboken, New Jersey, Vol. 1, pp.575-586.

PMI (2004) A Guide to the Project Management Body of Knowledge (PMBOK® Guide), 3rd ed., Vol. 1, Project Management Institute, Newtown Square, PA.

PMI (2007) Project Management Institute, Retrieved January 15, From http://www.pmi.org.

Podsakoff, P., Mackenzie, S.B., Bachrach, D.G. and Podsakoff, N.O. (2005) 'The influence of management journals in the 1980s and 1990s', Strategic Management Journal, Vol. 26, No. 5 , pp.473-488.

Porter, M.E. (1998) Competitive Strategy: Techniques for Analyzing Industries and Competitors, Vol. 1, The Free Press, New York.

Redding, S.G. (1994) 'Comparative management theory: jungle, zoo, or fossil bed?', Organization Studies, Vol. 15, No. 3, pp.323-359.

Shenhar, A.J. and Dvir, D. (1996) 'Toward a typological theory of project management', Research Policy, Vol. 25, pp.607-632.

Söderlund, J. (2002) 'On the development of project management research: schools of thought and critique', International Project Management Journal, Vol. 8, No. 1, pp.20-31.

Söderlund, J. (2003) 'Building theories of project management: past research, questions for the future', International Journal of Project Management, Vol. 22, No. 3, pp.183-191.

Söderlund, J. (2004) 'On the broadening scope of the research on projects: a review and a model for analysis', International Journal of Project Management, Vol. 22, No. 8, pp.655-667.

Tesch, D., Kloppenborg, T. and Stemmer, J. (2003) 'Project management learning: what the literature has to say', Project Management Journal, Vol. 34, No. 4, pp.33-39.

Turner, J.R. and Müller, R. (2003) 'On the nature of the project as a temporary organization', International Journal of Project Management, Vol. 21, No. 1, pp.1-8.

Ulri, B. and Ulri, D. (2000) 'Project management in North America: stability of the concepts', Project Management Journal, Vol. 31, No. 3, pp.33-43.

van de Ven, A.H. (1989) 'Nothing is quite so practical as a good theory', Academy of Management Review, Vol. 14, No. 4, pp.486-489. 
Weick, K.E. (1995a) 'Definitions', in Nicholson, N., Schuler, R.S. and van de Ven, A.H. (Eds.): The Blackwell Encyclopedic Dictionary of Organizational Behaviour (Blackwell Encyclopedia of Management), Blackwell Publishers, Oxford, England, Vol. 1, p.656.

Weick, K.E. (1995b) 'What theory is not, theorizing is', Administrative Science Quarterly, Vol. 40, No. 3, pp.385-390.

\section{Note}

${ }^{1}$ The term "projects as temporary organisations" is a European viewpoint that is not too dissimilar to a project being defined as a temporary undertaking to create a unique product or service (PMI, 2004; Turner and Müller, 2003). 